\title{
Penal Mediation in the Framework of Juvenile Deliquency in Albania: Education or Re-education
}

\author{
PhD Besnik Çerekja
}

Email: besnik.cerekja@gmail.com

Doi:10.5901/ajis.2014.v3n6p431

\section{Abstract}

The mediator gives room to conduct negotiations in criminal matters. Though, the scope of application of penal mediation, not only in Albania but beyond, is unfortunately limited to a restricted number of provisions, mainly referring to criminal contraventions. For instance, mediation is possible in cases of criminal offences related to bodily injuries, injury due to negligence, violation of domicile or cafés and so on but we will dwell on this topic latter while the Albanian legislation in the field of mediation will be analyzed. In all these cases and featuring a key characteristic of this Institute is the fact that mediation is not compulsory. Judicial authorities and all other operators of the justice system cannot force the victims or perpetrators of offences to consent to mediation procedure. This may occur in no case. The victims and perpetrators may and should jointly decide to initiate the mediation procedure, referring to the mediator or mediators. In respect of juveniles, as equally applied in the criminal and criminal procedural legislation, the organic law on mediation provides all necessary safeguards provided for in the domestic and international legislation (Paragraph No. 12 of Recommendation No. R (99) 19 of the Committee of Ministers addressed to the member states in respect of mediation in criminal matters (Approved by the Committee of Ministers on 15 September 1999 in the 697th meeting of the deputy ministers). The principle of confidentiality is another typical and core element for the functioning of mediation procedure, particularly in reference to cases of juvenile perpetrators or victims. This principle is translated to the confidentiality of not only cases/facts of concrete circumstances of cases but also the results drawn during the mediation process.

Keywords: Mediation, reconciliation, restorative justice, juvenile, criminal process, mediator, probation, diversion, victim, injured party, criminology, responsible, education, re-education, conflict.

\section{Analysis of Law No. 9090 Dated 26/06/2003 "On Mediation for Resolution of Conflicts"}

In 2003, through the new law on mediation the Albanian lawmaker, makes a radical intervention in the respective legislation, repealing the Law No. 8465 dated 11. 3. 1999 (Article 20 of Law No. 9090 dated 26.6.2003). It is worth stressing that the character and objectives of mediation are also incorporated in the new law, providing for: "Mediation is an extrajudicial activity in which the parties to the conflict seek the mediation of a third party to reach an acceptable resolution of the dispute..."

According to the new law, a mediator may be someone who meets the following conditions:

1. has turned 22 years old;

2. has completed University studies

3. has not been sentenced for intentionally committed offences;

4. has an appropriate moral and public figure for the mediation activity.

According to the previous law, the mediator should have turned 25 years of age and as a rule, should have completed Bachelor studies and be experienced in the field of mediation activity. This law also required higher education for the mediator, without posing the requirement of the type of studies followed by the mediator but we may naturally think that as a minimum, persons who have completed higher studies in social sciences may exercise that profession, considering the type of studies and formation of the students from those faculties.

Under the new law, the parties seek mediation of a third party or of a group of persons to reach an acceptable resolution being not contrary to law. Unlike the previous law, regarding the field of law application, according to provisions of article 2, mediation shall apply for the resolution of all disputes in the field of civil, commercial, family and criminal law, in conformity with articles 59 and 284 of the Criminal Procedure Code. As noted, compared to the previous law which clearly and precisely defined the fields of civil and family disputes (articles 10 and 11), the new law provides for the applicability of mediation process for all types of disputes, including the criminal ones.

Another principled amendment under the new law compared to the previous one is the fact that mediators 
exercising that activity as a profession, are obliged to register with the Court as natural persons or legal entities (subject to the fact if they will exercise the profession individually or collectively organized in offices or non-profit organizations) and in these cases, they have the right not only to recover the payments made for the purpose of mediation procedures but also to be paid for the work done (article 4, fourth paragraph). For this purpose, a preliminary signature of agreement with the parties would be crucial, without which this obligation recognized by law for the parties, could not be valid.

It is understood that such a provision is applicable for other non-profit organizations, including mediation within the scope of their activity, such as the arbitration for commerce but in no case for a non-profit organization such as the Foundation "Resolution of Conflicts and Reconciliation of Disputes".

The second paragraph of article 5 of the Law provides for a 30-day deadline within which the party requested to follow mediation procedures, should express its will for participation. In case of "silence", the requesting party shall deem it as non-acceptance of the invitation to mediate, referring to the judicial process resolution. In case of the acceptance of invitation, the mediation procedure shall start once the parties have agreed to follow procedures provided by law. The mediation procedure terminates on the day of signing of the agreement and other documents (written statement), as provided for in article 13 of the Law. This agreement is compulsory and enforceable to the same extent as arbitration awards (article 14).

Further, within the scope of provisions of this law, case procedures, data and circumstances remain confidential. Unless the parties otherwise agree, the mediator or the third party cannot claim or use in a judicial process, arbitration or another similar procedure, evidence or testimonies notwithstanding their forms in cases provided by article 12 of the Law.

Article 16 provides for that courts or arbitration do not institute or suspend the continuity of respective procedures, if the parties to a conflict being tried, have agreed beforehand to resolve the dispute by mediation and have expressly assumed, within a definite time limit or in proving a concrete circumstance, not to claim the dispute resolution by the arbitration court. Second paragraph of the article providing that "one of the parties may claim the commencement of trial by the court or arbitration to protect its rights" maintaining the court obligation under the provision of first paragraph, affords the opportunity to one party to refer to it in cases when it deems that its right is jeopardized.

As provided for in the previous law, within 45 days from the date when the case is brought from the court or prosecutor's office, the mediator shall inform them of the resolution or not of the dispute, sending them the respective acts.

The court or prosecutor's office may deem the agreement reached by mediation as invalid, when it draws the conclusion that the will of parties to the conflict is not manifested, their rights and interests are seriously violated or the paid compensation is clearly disproportionate to the damage caused. In its article 19 the law also provides for cases when the dispute settlement by mediation is invalid when:

a. realized by persons who are not mediators or should not be such according to law.

b. the dispute, according to law, should be judicially settled;

c. it contains obligations for subjects that have not participated in the mediation procedure;

d. there is simulation and for the real conflict, there are invalidity grounds.

The invalidity of mediation agreement under this law does not refrain the parties to the dispute to execute the concluded agreement by exercising the rights they enjoy under other laws. ${ }^{1}$ This provision enhances the morality and function of mediation process, which is and should be considered as an instrument in support of citizens, with whom the latter, assisted by field professionals, identify an expeditious and effective resolution of their case. Such a resolution is not affected even when the followed procedures are contrary to legal provisions (leading to the invalidity of act-agreement signed between the parties), thus making applicable only the express will of the parties to dispute, a will which may be executed by them at any time.

Regarding the mediation process for conflicts in criminal matters within the scope of this study, the new law does not bring a principled difference from the previous law in respect of the types of criminal offences which may be subject to mediation. According to article 2 of Law No. 9090 dated 26. 6. 2003, apart from the resolution of family, property and commercial disputes, mediation is also applied for the resolution of criminal disputes reviewed by the court upon the request of the accusing injured party or following the complaint of the injured party, pursuant to articles 59 and 284 of the Criminal Procedure Code.

The content of article 2 of Law does not differ from article 12 of the previous law (No. 8465 dated 11. 3. 1999).

1 In the same context, see also the manual of Prof. Dr. Ismet Elezi "Mediation for reconciliation of criminal disputes", Tirana 2004, pp. 199-200; 
Pursuant to article 59 of the Criminal Procedure Code, the accusing injured party has the right to submit a request for trial to the court in relation to the criminal offences provided by the Criminal Code as follows: Beating (article 90); Serious injury due to negligence (article 91); Slight injury due to negligence (article 92); Insult (article 119); Libel (article 120); Unfair interventions in private life (article 121); Divulgence of private secrets (article 122); Non-delivery of subsistence means (article 125); Illegal taking of child (article 127); Publication of another person's work (article 148); Publication of another person's work by one's own name (article 149); Breach of domicile inviolability (article 254). As for these offences, in addition to the accusing injured party, the prosecutor has the right to participate in the process. As appropriate, he/she may claim the sentence or innocence of the defendant. Before the case is brought for trial, the complaint shall be submitted to the police or prosecutor's office. Those bodies shall be obliged, with the consent of parties to the dispute, to bring the case for mediation to the mediation centers or mediators.

Pursuant to article 284 of the Criminal Procedure Code, the injured party has the right to submit a complaint for criminal prosecution and may withdraw it at any stage of the proceeding and claim the employment of mediation procedures for the following criminal offences: Slight intentional injury (article 89); Violent sexual relations with adults (article 102); Sexual or homosexual relations in abuse of office (article 105); Sexual or homosexual relations with blood relatives (article 106); Coercion or prevention to cohabitation or marriage dissolution (article 130); Libel in abuse of office (article 240); Libel to the President of the Republic (article 241); Assault against the family members of the person holding a public office (article 243); Obligation to participate in strike or not (article 246); Malevolent use of phone calls (article 275); Insult of judge (article 318).

In the spirit of law, the primary objective is prevention of criminal disputes and continuous improvement of the quality of mediation process, in order to have a sustainable agreement reached between the parties to dispute. This requires an increase of cooperation of the mediation centers and mediators with the public order police and judicial bodies and with all other operators such as the prosecutor's office, court, local government, which, due to the office they hold, play a key role to achieve the purposes of law.

\section{Current Overview on Mediation. Law No. 10385 Dated 24/02/2011 "On Mediation for Settlement of Disputes"}

As also stated by Prof. Dr. Mariana Semini-Tutulani in the introduction of the commentary of law "On Mediation For Settlement Of Disputes" No. 10835 dated 24. 02. 2011, among the three laws promulgated on mediation after "90s, that one has upgraded the professional and organizational level of the process of extrajudicial mediation of conflicts and disputes. Its implementation is undoubtedly expected to bring positive effects on the society as it improves the peaceful climate between people and significantly reduces the work volume within the judicial bodies.

According to Law No. 10385 dated 24. 02. 2011 "On mediation for settlement of disputes" fundamental steps are launched and a more advanced stage is reached. The institute of mediation in the Albanian civil and criminal law is fully regulated by stipulations and provisions of Law No. 10385 dated 24/02/2011 "On mediation for settlement of disputes". The first Chapter of this law under the item "General Provisions" defines the meaning of the institute of mediation, scope of application and general principles of operation of mediation in the Albanian law.

The meaning of mediation is given in provisions of article 1 of this law, specifying that: "Mediation is an extrajudicial activity in which the parties claim the resolution of a dispute via a third unbiased party (mediator) to reach an acceptable dispute resolution being not contrary to law". The mediator's characteristics, that is being a third party and independent from the parties to dispute, are distinguishing elements included in this law. These features of the mediator are so necessary that they are considered objective and basic requirements to be deemed as such, without which the process oriented to a positive resolution would not be possible.

According to the definition ascribed by the lawmaker, we may define that:

a. a-"Mediation" is an extrajudicial activity of the mediator for the amicable resolution of the dispute arisen between the parties.

b. b-"Mediator" is the individual who has no connection or interest in the dispute of the parties to conflict. He/she exercises his/her activity independently and in accordance with the provisions and requirements of this law and bylaws adopted for its implementation by the Council of Ministers and the Ministry of Justice.

c. c- Actions of the mediator have no binding character for the parties to conflict. The purpose recognized by the lawmaker regarding his/her activity is related to the identification and reaching of acceptable resolutions by the mediation parties.

It is worth stressing that mediation activity is carried out under the inspection of the Ministry of Justice, which guarantees and supervises this crucial activity for the community. 
Scope of application. A key component provided by this law is that mediation in criminal and civil processes cannot be instituted and realized contrary to the will of parties to the dispute, regardless of the fact if this conflict is sought or not to be solved judicially. Article 2 of this law is binding that in view of conflict resolution by mediation, the express will of parties to the dispute shall be expressed without referring to the court. This provision also foresees that the court or respective state body may guide the parties to mediation procedure after setting in motion the conflict resolution (clause 1 of article 2 of the Law), which means that the court, not only when requested by the parties but also ex officio, may guide the parties to the mediation process.

The second and third paragraphs define the scope of application of the institute of mediation acting for the settlement of all disputes in civil, commercial, labor and family matters, and in criminal matters for the disputes reviewed by the court upon the request of accusing injured party or on the basis of complaints of the injured party, according to articles 59 and 284 of the Criminal Procedure Code'2. Provisions of paragraphs 4 and 5 of article 2 of this law about the obligation of the state body or the court on notification of parties for the settlement of dispute by reconciliation, complies with the stipulations made by civil and criminal procedural provisions. In this provision the lawmaker has excluded cases which cannot be claimed or resolved through mediation such as the lawsuits of property character amounting to 500.000 ALL or cases of conflicts that may be settled by mediation. The fifth paragraph of article 2 of the Law obliges the Court that in cases of disputes in criminal matters, as provided by the third paragraph of the same article, it shall suspend judicial investigation and invite the parties to refer to the conflict resolution by mediation.

Article 3 of the Law foresees the general principles on which mediation activity is based. First paragraph of this provision provides for that mediation activity should be based on the principle of equality of arms, confidentiality of data transmitted to the mediator in the course of this process, as well as flexibility and transparency of actions carried out for the parties during mediation.

Confidentiality of data, facts and anything else discovered during the mediation process is an aspect of special importance and non-derogable for that institute and the subsequent process. In no case, the parties to dispute shall launch any initiative to participate in the mediation process, if they are not sure that their story would remain confidentialsecret. This is precisely one of the factors distinguishing mediation from the traditional judicial process and urging the parties to dispute to refer to the mediator, establishing the belief and being assured from the latter that their story would remain anonymous, either in case of a negative outcome of the process. To put it differently, even in case when the mediation process failed to extrajudicially resolve the conflict between parties, the outcomes thereof cannot be made public and used by the court during judicial review of the case, unless there is a consensus for that purpose between the parties to dispute.

Pursuant to the provisions of this law, mediation process cannot be realized if one of the parties does not consent to resolve the issue by mediation. The parties are free to adopt attitudes according to their will, without being influenced by the advice, actions or recommendations of the mediator.

As highlighted above, a main feature of mediator is his/her impartiality in exercising the profession, obliging him/her in no case to adopt a unilateral attitude or advice one party or another, limited only to the direction of parties toward the achievement of conflict resolution.

Further, mediation needs to be voluntary in order to have a voluntary participation of litigants and they are free to waiver at any time from the resolution of dispute by mediation. The mediator does not assume any responsibilities to the parties if at the end of the process, no agreement is reached between the parties or when the agreement is not respected after its conclusion. This safeguard granted to the mediator realizes or at least guarantees his impartiality during the process, so that he/she shall not be bound to take sides of any of the parties due to the fear of not achieving the desired result, thus urging the parties to dispute to a forced "solution".

The Law provides for cases of disputes in criminal matters for which when the criminal process has been instituted, the court shall invite the parties to resolve disputes by mediation. It further specifies that disputes for which judicial resolution is compulsory, cannot be resolved by mediation. This last provision limits the scope of actions of mediators and consequently of the parties to disputes, strictly excluding the disputes over which the only resolution option would be the

${ }^{2}$ Article 59 of the Criminal Procedure Code has grouped the criminal offences for which the accussing injured party directly claims the criminal prosecution to the district court against the accused party, who has committed the offence to the detriment of the injured party. As regards the criminal offences defined under article 284 of the Criminal Procedure Code, provision is made for those offences for which the criminal prosecution is instituted only on the basis of penal complaint of the injured party. In these complaint cases, the report by the injured party for the commencement of the criminal prosecution shall be submitted to the judicial police and prosecutor, unlike the criminal offences defined under article 59 of the Criminal Procedure Code. 
judicial process.

Experience of countries with more advanced legislation and a more open mentality referring to individuals constituting the community, has shown this is a limit that may be exceeded but which requires a higher level of sensitization and awareness of the individual as part of the community. In a country like Albania, it is prerequisite to define by law a restriction of the scope of mediation and mediator's activity, as otherwise, from an instrument prone to favor the victim of offence, would place the latter under strong pressures from the perpetrator or his relatives, which would require at any rate the participation of victim in mediation, in order to derive benefits from participation in this process also for low social risk offences.

Licensing and exercise of mediation activity is regulated by provisions of articles 4, 5, 6, 7 and 8 of this law. These clauses envisage that mediation is a free-lance licensed profession (and consequently supervised) by the Ministry of Justice and is regulated by provisions of this law and other bylaws stemmed for its implementation. The structure and organization of this service is based on the one of the notary and lawyer's service in the Republic of Albania. These provisions have specified the requirements for being a mediator and exercising this profession in the Republic of Albania and in general of the whole process of licensing of that activity.

Mediation is a profession. Therefore, as such the mediator has the right to be remunerated for the work done, notwithstanding the achievement or not of the concrete outcome. Accordingly, as the lawyer's profession, it is about an obligation oriented to means and not result. Article 10 of the Law provides for the mediator's duties. Therefore, it defines obligations supporting the role of mediator between the parties.

Further, article 11 has foreseen the incompatibility for implementation of this activity in cases of conflicts of interests with the mediation parties or subject. Referring to the obligation on absence of the conflict of interest between him/her and parties participating in a mediation process, by analogy with articles 15 and 16 of the Criminal Procedure Code, respectively "Incompatibility due to participation in proceeding" and "Incompatibility due to family, kin or in law ties", we may admit that the mediator cannot participate in a mediation process if:

a) the mediator has a personal interest directly linked with him/her or his/her relatives in respect of the matter for which mediation is sought;

b) the mediator is a custodian or representative of one of the parties;

c) the mediator, spouse or his/her relatives to the second degree are involved in a judicial conflict, credit or loan agreement with one of the parties;

d) there is a serious and sufficient ground demonstrating a conflict of interest situation.

Once again, these obligations represent a guarantee for the participating parties as they ensure the mediator's impartiality and his/her lack of interest in the final aim of the process, namely the achievement of a result at any rate.

On the basis of the foregoing, when a person is granted the opportunity to be chosen as a mediator, he/she shall declare and inform the parties of any circumstances that may harm or cause doubts to his/her impartiality and independence regarding the concrete case, subject to mediation. Starting from the time of assignment and during the whole period of mediation procedure, the mediator should declare without delay to the parties any circumstances that may constitute a violation or doubt to his impartiality and independence.

In conclusion, regarding the final provisions provided under the fourth Chapter of law, we may admit that the lawmaker, in article 25 has also foreseen the obligation of respective institutions to draft and adopt bylaws for implementation, and in article 26, with the transitory provisions it has scheduled a 6-month deadline to regulate professional relations of the mediators. These should be submitted to the Ministry of Justice, an institution administering the respective register.

Upon the entry in force of this law, the Law No. 9090 dated 26/06/2003 "On mediation for settlement of disputes" is fully repealed (Law No. 10385, dated 24/02/2011 "On mediation for settlement of disputes", Article 27).

\section{Conclusions and Recommendations}

We made a historical-legal interpretation and analysis of the Albanian legislation in force in the field of mediation, starting from the law of 1999, with the sole purpose of providing a comprehensive framework of the current legislation in Albania and not because these laws provide key elements regarding the main scope of this study which is directly linked with the juvenile perpetrator. As it may be easily observed, the respective provisions pay only peripheral attention to mediation in criminal matters and almost no element is relevant or dedicated to mediation for juveniles, either be perpetrators or victims. This is a clear overview and direct expression of culture reflected by the mediation process, a culture which observes, accepts and attempts to resolve the conflict within the social community it originates from. 
As above, we easily draw the conclusion that in Albania, the path to culture of mediation in general and of the criminal one in particular, should be still cultivated in the minds of Albanian citizens.

Information on the new law on mediation, assimilation of values and principles it carries, is necessary not only for mediators but also for other state bodies, especially police, prosecutor's office, court, local government, which are the first stakeholders to come in contact with the perpetrator and his/her victim.

Information about the organic law and knowledge on mediation are also essential for the community, which is directly interested to know what mediation is and advantages it brings toward the judicial conflict settlement. For this purpose, inter alias, a public awareness program would be necessary, either by educational programs foreseen since elementary school cycles or by media programs that would increase its publicity, sensitization and efficacy. In this respect, it would be worth to consider training sessions of justice system operators, members of social and public order services, judicial police officers, lawyers, psychologists, prosecutors, judges and anyone else who, due to their profession, come in contact with the juvenile, in view of their professional development and increase of crosscutting cooperation.

Another group where knowledge and application of mediation techniques and culture is required is the one of educators, teachers, lecturers or other stakeholders, including all those who in their daily life, due to their work, come in contact with the juvenile. A series of studies conducted by field researchers, place the focus on the need of formation of young generation. As also stated in articles of Prof. Assoc. Dr. Qazim DUSHKU (Q. DUSHKU, "Adolescents in the long road of conflicts") ${ }^{3}$, education and formation of young generation is realized to a certain extent through cooperation, coinfluence and mutual interaction of many factors and stakeholders, where the main role is played by teachers, their academic and professional formation level. In the context of mutual interaction between teachers and pupils, teachers and parents, pupils and parents, pupils, school and community and so on, values are confronted with anti-values, knowledge with lack of knowledge and so on.

Only a sound education of those generations by a well-prepared, qualified and highly professional teaching staff, capable of not only mediating successfully controversial cases to be brought during daily work but also to prevent emerging conflicts, will always make them prone to peaceful resolution of conflicts. Otherwise, these members of teaching staff will become a source of deviant and conflicting behaviours, worsening the climate of coexistence within school premises.

Disputes and conflicts cannot be terminated by a teacher and lecturer, who lack respective education, necessary experience and basic knowledge on communication and psychic world of pupils, their age ${ }^{4}$ and psychology. Therefore, educators and teachers need to be familiar with mediation techniques, thus upgrading the educational and cultural level of the teaching staff they are part of.

As also mentioned during the analysis of Law No. 8465 dated 11. 3. 1999 "On mediation for settlement of disputes by reconciliation", repealed, we noted that the highest integrity permeated by the spirit of this law but also carried by the current legislation in force as one of the basic functions of mediation process, is the fact that in the mediation process for reconciliation, both parties are winners in amicably resolving the dispute by respecting each other's individual values. Mediation impartiality is manifested during this process, thus enhancing its authority, belief and values.

Article 6 of the Law provides for that mediation is a mutual educational process intended to prevent judicial settlement of disputes and mitigate their social consequences, harmonize the interests of parties by creating mutual understanding between them. Mediation aims to challenge consequences deriving within social groups as a consequence of criminal offences or other disputes.

The most important element conveyed by this provision is the fact that it attached importance to the protection of interests and values of social community, which should be protected from the consequences deriving as a result of criminal or civil conflicts generated from the conflict. In this meaning, a key component to be envisaged would be the involvement of community members during the mediation process. Only members of the community in which the conflict has emerged and developed, may "judge", adding to the need "to render justice or to trial objectivity, the element of subjectivity, namely the personal and social evaluation that only members of that social-cultural group would present to the "final decision" or resolution of that conflict by agreement.

This element clearly reflected in the law of 1999 but which could not be practically implemented, is not any longer

${ }^{3}$ Published in the semi-annual sociological, legal and cultural magazine "Mediation" Issue 2 (27) of the year 2007-publication of the Foundation "Resolution of Conflicts and Reconciliation of Disputes", page 41.

${ }^{4} \mathrm{Ibid}$, page 53. 
incorporated in the law of 2003, neither in the law of 2011. That fact clearly shows "immaturity" of our social community, which does not seem capable to "judge" objectively, giving added value to the agreement that may be reached by the end of mediation process. However, this element has been sufficient to attach value to mediation procedures launched in relation to "reconciliation of bloodfeuds", processes during which the mediators are often helped by members of the respective communities or mediators themselves have been members of those socio-cultural communities.

Recommendations. Further to what we outlined in the beginning of this study and as concluding remarks, apart from the relevant conclusions, I would like to posit some recommendations, which from my modest perspective, would prove effective and productive if they are taken into account and are practically implemented.

From an economic perspective, statistics show that fines imposed to the offence perpetrator or perpetrators, even if not enforced, cannot equal the costs to be afforded by the state to maintain the whole justice system, penitentiary administration and any other institutions involved. Therefore, it becomes a prerequisite to implement reforms leading to another direction of criminal policies, to a different channelling of funds that currently go in favour of the further maintenance and development of penitentiary administration. Obviously, this leads to the conclusion that only by being oriented to a system preventing criminal offences, we will gradually reduce the number of offences and their perpetrators, progressively reducing not only overcrowding in prisons but also the number of victims who suffer crime consequences.

The aim and implementation of reforms leading to this system naturally reduce costs for the maintenance of penitentiary administration, funds to be oriented to educational programs. In this framework, I would like to reiterate the fact that those educational and not re-educational programs should begin to be applied at the earliest life stages. Field specialists, educators, teachers, psychologists and so on admit that educational programs should begin as early as in kindergartens because in these institutions children acquire initial information about the coexistence and living within a common community.

To be more audacious, I may admit that similar programs and good manners seem to be applied since the nursery years (referring to children until 3 years of age) as they are the institutions where the future "perpetrator" and "victim" receive initial information about the coexistence in a community. They are the venues where they learn how to negotiate. In the nursery a child learns that to acquire a toy he/she likes but currently held by another child, he/she should ask for it politely or give something else to the other child such as another toy in return, so that both children (both parties) benefit from the exchange. In this case the educator may play a highly instrumental role of mediator for the child.

At this point, we penetrate the very core of mediation, a process from which, as we have stated in more than one case, both parties are winners being faced with minimum costs of "dispute" management. Ideally, mediation principles are embedded in education, behaviour and psyche of the members of a social community. Individual members of a social community with culture, education, lifestyle and mentality based on the settlement of disputes by mediation represent the best "market" and "the best and most appropriate material resources" for the work of mediator. "Open minded" is an internationally applied term in this field, the most relevant feature attributable to this category of people-members of a community.

The dream of every mediator is to work with open minded perpetrators and victims as they are easily oriented to the resolution of their conflict by mediation. Most probably, they will have no need to be oriented and seek the mediator's intervention as their culture and mentality are prone to extrajudicial conflict resolution.

To further continue, public awareness of the role of importance of mediation for reconciliation of conflicts by using different forms of publicity, such as written and visual media, has had and will have priority. Special attention is also paid to the continuous training of mediators, claiming the assistance of highly qualified local and foreign trainers.

Regarding the sources mediation cases are referred to, community seems to be the most important one. If we refer to some statistical data about practical cases, it follows that compared to previous years, cooperation with the institution of prosecutor's office has been substantially increased. Seminars conducted with prosecutors and judicial police officers have established a sound institutional basis for mediation of criminal disputes by reconciliation. However, we are sure these are not adequate efforts.

What needs to be done for the purpose of a successful and effective mediation is the education of community members, starting with educational programs since the early life stages, when we believe that human education begins. As we stated above, nurseries or kindergartens are institutions where children's education should begin. This is not basically related to the information on legislation and advantages of mediation process as it would be a failed effort if we refer to the young age of those attending such institutions of care and education.

However, they instil the spirit of tolerance, mutual understanding, trust in themselves and in others. In this way, with a social community consisted of grown individuals educated under similar programs, we may prevent in the future emerging conflicts and criminal offences. Acts of violence and vandalism in these communities would not only be 
prevented but the settlement of these disputes would be easier for the purpose of intervention and impact of social community on the individuals involved. These are the most significant effects of positive results reached by mediation processes.

Other key stakeholders for the effectiveness of educational process would be the elementary and secondary schools, which are the venues where children, in application of educational programs approved by the Ministry of Education and Science (presently referred to as the Ministry of Education and Sport) continue not only to be educated under the sound values of citizenship but also to receive valuable information about various forms of prevention and resolution of conflicts emerged in the society.

One of them is precisely the institute of mediation for extrajudicial resolution of conflicts to be provided by the community and for this reason it proves to be the most effective one. We persist in our belief that only in this way the society will carry mediation values, making it highly effective in settling disputes and not remaining in the formal perspective, as an additional provision in the endless number of national norms and standards.

Fight against corruption in general and in the justice system in particular would also prove to be an effective instrument for the increase of cases of disputes to be settled via mediation procedures. Reforms in justice system have critical importance to ensure the independence of courts and effective battle against corruption. A corrupt-free judicial system would generate broad opportunities for the courts to reconcile parties in those cases expressly provided by the Criminal Procedure Code and Civil Procedure Code (referring to civil disputes), thus increasing the number of cases when parties would settle their disputes by mediation.

In the wake of recommendations on the need for implementation of legislation reforms, pursuant to articles 59 and 284 of the Criminal Procedure Code, we share the same opinion with those authors and researchers and above all with Prof. Dr. Ismet ELEZI, suggesting amendments to the Criminal Procedure Code in the near future, from the moment when these provisions are not practically implemented.

Let us think and hypothesise for a moment the potential mediation between the perpetrator and the injured party, in case of the commission of criminal offence provided by article 241 of the Criminal Code "Libel against the President of Republic". We may admit the same for other provisions such as "Libel due to office" provided for in article 240 of the Criminal Code or "Sexual or homosexual relations in abuse of office" (article 105 of the Criminal Code). In particular, referring to the latter we believe that mediation cannot be implemented and not because of the sentence term provided for the perpetrator, ranging up to three years of imprisonment but because the Albanian society still lacks the proper cultural level, necessary and adequate awareness to understand potentials and advantages brought by mediation.

Theoretically and in principle I share the opinion that mediation is prone to encounter growing limitations in terms of types of criminal offences for which it may be implemented and applied, at least from the perspective of "benefit" to the victim or injured party under this process but I am also positive that these versions are proportionate to educational and cultural level of individuals constituting the community. If this may be easily observed during the analysis of countries like Norway, USA or Canada, we cannot admit the same for the current state of affairs of Albania in terms of cultural and educational level of its citizens.

I am not apt to deem as useless the work done to date in the field of mediation. However, I remain confident that in a country where it is not made possible the uprooting of bloodfeud, mediation culture still requires efforts and many years of work to launch initial steps to change the mindsets and self-awareness of members of that community.

Finally, training of justice operators would prove useful such as judges, prosecutors, judicial police officers, police agents, psychologists, operators of social service etc, regarding the mediation and respective procedures regulated by law as in this way they would implement those procedures more effectively, thus enabling the immediate exclusion of juveniles from the justice system, entrusting it to the mediation process and mediator, returning juvenile perpetrators to the social community they belongs to.

At the same time, successful implementation of mediation process would bring benefits for the victim or injured party not only financially but in particular from the psychological perspective, specifically their rehabilitation in terms of negative consequences suffered from crime.

\section{References}

Recommendation No. R (99) 19 of the Committee of Ministers referred to member states regarding mediation in criminal matters (Approved by the Committee of Ministers on 15 September 1999 in the 697th meeting of deputy ministers).

Parlamenti i Republikës së Shqipërisë, (Law No. 7905 dated 21. 03. 1995), Criminal Procedure Code of the Republic of Albania, as amended.

Parlamenti i Republikës së Shqipërisë, (Law No. 7895 dated 27. 01. 1995), Criminal Code of the Republic of Albania, as amended. 
Parlamenti i Republikës së Shqipërisë, (Law No. 8465 dated 11. 03.1999) "On resolution of conflicts and reconciliation of disputes".

Parlamenti i Republikës së Shqipërisë, (Law No. 9090 dated 26/06/2003) "On mediation for settlement of disputes".

Parlamenti i Republikës së Shqipërisë, (Law No. 10385 dated 24/02/2011) "On mediation for settlement of disputes".

General Assembly of United Nations Organization (20 November 1989) "Convention on rights of child".

Elezi I, (2004) "Reconciling mediation in criminal disputes", Tirana.

Cris M. Carrie, (2001), "Should the mediator be among legal experts or lawyers", Reconciliation.

Commentary of Law No. 10385 dated 24/02/2011 "On mediation for settlement of disputes"- Publication of the year 2012 prepared by a group of field experts, with the coordination of the Foundation "Resolution of Conflicts and Reconciliation of Disputes" and the School of Magistrates, under the auspices of UNICEF and IFC.

Dushku Q, (2007) "Adolescents in the long road of conflicts"- sociological, legal and cultural magazine "Mediation", Tirana. 
